OPEN ACCESS

Edited by:

Detlef Neumann,

Hannover Medical School, Germany

Reviewed by:

Cinzia Fionda,

Sapienza Università di Roma, Italy

Fons Van De Loo,

Radboud University Nijmegen

Medical Center, Netherlands

*Correspondence:

Victoria del Pozo

vpozo@fjd.es

Specialty section: This article was submitted

to Cytokines and Soluble Mediators in Immunity,

a section of the journal

Frontiers in Immunology

Received: 21 April 2017 Accepted: 29 June 2017

Published: 21 July 2017

Citation:

Sastre B, Cañas JA, RodrigoMuñoz JM and del Pozo V (2017) Novel Modulators of Asthma and Allergy: Exosomes and MicroRNAs.

Front. Immunol. 8:826. doi: 10.3389/fimmu.2017.00826

\section{Novel Modulators of Asthma and Allergy: Exosomes and MicroRNAs}

\author{
Beatriz Sastre ${ }^{1,2}$, José A. Cañas ${ }^{1,2}$, José M. Rodrigo-Muñoz ${ }^{1,2}$ and Victoria del Pozo ${ }^{1,2 *}$ \\ ${ }^{1}$ Laboratory of Immunoallergy, Department of Immunology, IIS-Fundación Jiménez Díaz, Madrid, Spain, ${ }^{2}$ CIBER de \\ Enfermedades Respiratorias (CIBERES), Madrid, Spain
}

Intercellular communication is crucial to the immune system response. In the recent years, the discovery of exosomes has changed the way immune response orchestration was understood. Exosomes are able to operate as independent units that act as mediators in both physiological and pathological conditions. These structures contain proteins, lipidic mediators, and nucleic acids and notoriously include microRNAs (miRNAs). miRNAs are short RNA sequences (around 19-22 nucleotides) with a high phylogenetic conservation and can partially or totally regulate multiple mRNAs, inhibiting protein synthesis. In respiratory diseases such as asthma and allergic sensitization, exosomes released by several cell types and their specific content perform crucial functions in the development and continuation of the pathogenic mechanisms. Released exosomes and miRNAs inside them have been found in different types of clinical samples, such as bronchoalveolar lavage fluids and sputum supernatants, providing new data about the environmental factors and mediators that participate in the inflammatory responses that lead to the exacerbation of asthma. In this review, we summarize our current knowledge of the role of exosomes and miRNAs in asthma and allergic sensitization, paying attention to the functions that both exosomes and miRNAs are described to perform through the literature. We review the effect of exosomes and miRNAs in cells implicated in asthma pathology and the genes and pathways that they modify in them, depicting how their behavior is altered in disease status. We also describe their possible repercussion in asthma diagnosis through their possible role as biomarkers. Therefore, both exosomes and miRNAs can be viewed as potential tools to be added to the arsenal of therapeutics to treat this disease.

Keywords: exosome, microRNA, asthma, allergy, inflammation, intercellular communication

\section{INTRODUCTION}

Cellular communication is a key feature of the immune response. This communication is mainly done by cytokines, chemokines, and other soluble mediators. But in the past decade, extracellular vesicles have become recognized as players in these intercellular communications. There are a variety of these extracellular vesicles that have now been studied, and one of them are the exosomes, that contain a wide variety of molecules inside. One of them are microRNAs (miRNAs), important elements linked to regulation of functional cellular mechanisms that open a new door to genetic regulation (1). So, new almost unexplored areas of knowledge are emerging. 
Exosomes are small vesicles $(10-150 \mathrm{~nm})$ released into the extracellular space after the fusion of multivesicular bodies (MVBs) with the cell membrane. They are secreted by several types of cells-among them, cells implicated in allergy and the immune response, including $\mathrm{B}$ and $\mathrm{T}$ lymphocytes, dendritic cells (DCs), mast cells (MCs), epithelial cells, and macrophagemonocyte cells (2-7) — and, as recently discovered by our group, by eosinophils (8). Also, other cell types, such as hematopoietic cells (reticulocytes), platelets, microglia, and some tumor cells, also produce exosomes (9-12). This etiologic heterogeneity led to find exosomes in a large variety of body fluids, including blood, amniotic fluid, urine, breast milk, and saliva, under physiological and pathological conditions $(13,14)$. Moreover, analysis of bronchoalveolar lavage fluid (BALF) and nasal lavage fluid documents that exosomes can be found on respiratory mucosal surfaces (15-17).

So, exosome secretion provides cells with a mechanism for rapid release of a selective repertoire of molecules, such as proteins, mRNA, lipids, and miRNAs. Once in the extracellular space, the exosomes can be taken up by neighboring cells or enter the circulation and travel to distant sites in the bloodstream, modulating the activity of receptor cells. Thus, exosomes have been implicated in a broad range of biological processes, such as immune regulation, inflammation, cancer progression and metastasis, neuronal communications, and lung diseases (18-22).

These structures commonly contain tetraspanins (CD63, CD81, and CD9), transmembrane receptors (integrins $\beta 1$ and $\beta 2$ ), membrane-trafficking proteins, adhesion molecules, lipid rafts, costimulatory molecules, proteins involved in MVBs formation, major histocompatibility complex (MHC) of class I and MHC of class II in the membrane, metabolic enzymes, chaperones, cytoskeletal proteins, signal transduction proteins, and nucleic acids. An important characteristic of exosomes is that their specific protein composition depends on their cellular or tissue origin and may differ according to the physiological or pathological situations that activate exosome release. Moreover, other components of exosomes include lipids (cholesterol, diglycerides, and phospholipids) and bioactive agents [prostaglandins and leukotrienes (LTs)] $(23,24)$. In addition, exosomes contain DNA and RNA molecules, including mRNAs and miRNAs, with important regulatory roles $(25,26)$.

Thus, exosomes are "professional transporters and messengers" to systemic level making them a possible tool for the therapeutic delivery of small interference RNAs (siRNAs), miRNAs and short

\footnotetext{
Abbreviations: AECs, airway epithelial cells; AHR, airway hyperresponsiveness; APCs, antigen-presenting cells; ASMCs, airway smooth muscle cells; BALF, bronchoalveolar lavage fluid; BECs, bronchial epithelial cells; COPD, chronic obstructive pulmonary disease; COX, cyclooxygenase; DCs, dendritic cells; ECP, eosinophil cationic protein; EDN, eosinophil-derived neurotoxin; EPO, eosinophil peroxidase; HSP, heat shock protein; ICAM, intercellular adhesion molecule; IFN- $\gamma$, interferon-gamma; LFA, lymphocyte function-associated antigen; LTs, leukotrienes; MBP, major basic protein; MCs, mast cells; MDM, monocyte-derived macrophages; MHC, major histocompatibility complex; miRNAs, microRNAs; MVBs, multivesicular bodies; PBMCs, peripheral blood mononuclear cells; qPCR, quantitative PCR; shRNAs, short hairpin RNAs; siRNAs, small interference RNAs; sTNFR, soluble tumor necrosis factor receptor; Th, T helper; TNF- $\alpha$, tumor necrosis factor alpha; VEGFA, vascular endothelial growth factor A.
}

hairpin RNAs (shRNAs) (27), or another kind of tools such as anti-inflammatory or/and anticancer agents (28-30).

In summary, exosomes are implicated in several processes related to immunoregulation (31), protective immune responses to infections (32), asthma (33), and allergy (3). The focus of this review is on the role of exosomes and miRNAs in the pathology of asthma and allergy.

Much of functional importance of exosomes lies to their role as "miRNAs containers." miRNAs, are the best-known RNA subtype within a larger group of nucleic acids called "small RNAs," an arbitrary term that was previously used for other non-coding RNAs such as small nuclear RNAs and transfer RNAs. The miRNAs are single-stranded RNAs with a length of approximately 22 nucleotides (mature miRNAs) generated from endogenous hairpin transcripts (34).

Currently, there are more than 2,500 entries for mature miRNAs in humans (35). A high degree of phylogenetic conservation has been observed between miRNAs of bilaterian animal, which implies that miRNAs have a crucial role in animal evolution (36). Mammalian miRNA genes have multiple isoforms (paralogs) that often have identical sequences at nucleotide positions 2-7 relative to the $5^{\prime}$ end that are called "seed sequence." These six nucleotides are decisive in pairing with target mRNAs (37), conferring upon miRNAs one of their most important characteristics, namely promiscuity behavior. So, this feature implies that one miRNA can regulate multiple (several hundred) different mRNAs (38).

Some miRNAs are originated in independent transcription units (39) although approximately 50\% of mammalian miRNA loci are in close proximity to other miRNAs. They can form clusters, and these can be interrelated, but this situation is not always bidirectional. So, they could be related between them but they do not form a cluster (40).

MicroRNAs regulate the expression of genes through two methods: translational repression and degradation of mRNA. These effects will depend on the degree of sequence complementarity between the miRNA $5^{\prime}$ region and the mRNA $3^{\prime}$-untranslated region (40-42). In animals, miRNAs bind to complementary sequences located in their target mRNAs, totally or partially inhibiting protein synthesis (43) and exerting an important effect at the translational level without modifying the mRNA load (44). A single miRNA can exert repression on multiple mRNAs. In this respect, mutation experiments have probed two classes of target mRNAs. One type of target exhibits a perfect Watson-Crick complementarity at the mRNA $5^{\prime}$ end. In this case, additional base pairing is not necessary. The other class has an imperfect $5^{\prime}$ end, but this is compensated by base pairing at the $3^{\prime}$ end of the miRNA (45). Thus, miRNAs are the regulators of protein synthesis at the post-transcriptional level and modulate gene expression by translational repression or degradation of a specific mRNA.

The most important trouble in miRNA study field is their target identification (46). Computational programs based on sequence alignment have been developed to perform predictions of miRNA targets. These predictions are more complex in animal RNAs, because complementary sequences are more imperfect than in plants. Computational tools are based on evolutionaryconserved regions and target-binding sites (47-49). The following two classes of bioinformatics platform exist: experimentally 
verified miRNA target databases and computationally predicted miRNA target databases.

So, exosomes and miRNAs are new players that could exert relevant effects in physiologic and pathologic mechanisms and that is not all, they could have an important role in new diagnostic and therapeutic approaches.

In the present review, we summarize the role known so far of exosomes and miRNAs in respiratory diseases, specifically, allergy and asthma pathology.

\section{EXOSOMES IN ASTHMA AND ALLERGY}

Several cell types implicated in asthmatic and allergic processes can release exosomes that contribute to these pathologies. It is necessary to take into account the exosome load and composition and how this may depend on the cellular origins. So, both effector and structural cells implicated in asthmatic pathophysiology contribute to exosome pool that acts in inflammatory context that characterize this disease.

\section{Exosomes from DCs and Monocyte- Macrophages}

Dendritic cells are a specialized cell type of mammalian immune system. They mediate innate immunity and they are able to phagocyte pathogens, but their principal function is to process and to present antigens to T-lymphocytic cells. They are antigenpresenting cells (APCs) with the essential properties required for the effective induction of an immune response (50). Several studies have demonstrated that these cells are able to secrete exosomes; and like their parent cells, these exosomes contain MHC molecules of both classes (I and II), and they are able to specifically stimulate T-cell responses, using indirect interaction mechanisms (51). DC-derived exosomes develop these responses by direct contact with $\mathrm{CD}^{+}-\mathrm{T}$ cells or via the capture of these exosomes by other APCs $(51,52)$.

Dendritic cell-derived exosomes can carry aeroallergens and contribute to allergic inflammation, as previously described by Vallhov et al. (3). These nanovesicles are able to present allergens and to induce the production of T helper (Th) 2 cytokines in $\mathrm{T}$ cells in allergic subjects. These exosomes can to induce interleukin (IL)-4 responses in peripheral blood mononuclear cells (PBMCs) from cat-allergic donors and not in feline-antigen tolerant donors, when exosomes present the antigen Fel $\mathrm{d} 1$. These findings may be important for future exosomes engineering to create exosome-based vaccines for immunotherapy.

Previous studies have characterized the surface protein components of exosomes from DCs. Admyre et al. (53) determined that monocyte-derived DC exosomes express several molecules such as HLA-DR, MHC class I, CD63, CD86, and CD54. The presence of CD63 confirmed the endosomal origin of these vesicles, and CD86, which is a costimulatory molecule, showed the implication in clonal expansion and differentiation of T cells. Through CD54 (an adhesion molecule), exosomes can interact with lymphocyte function-associated antigen (LFA)-1 present in T cells.

In contrast, the release of monocyte-derived macrophage (MDM)-derived exosomes is modulated by several factors.
Regulatory cytokine transforming growth factor beta 1 (TGF- $\beta 1$ ) affects exosome formation to decrease the rate of exosome delivery (7). Also, the Rab guanosine triphosphate phosphatases serve as master regulators of membrane trafficking and they are involved in the exosome release mechanism (54). In contrast, cytokines such as IL-1 $\beta$ induce microvesicular shedding from peripheral blood monocytes (55) and interferon-gamma (IFN- $\gamma$ ) produces an increase in exosome secretion by alveolar macrophages (6). So, it has been hypothesized that lung macrophages might be a source of exosomes implicated in Th1 but not Th2 inflammation; although this possibility must be confirmed.

Besides exosome antigen-presenting capacity, MDM- and DCs-derived exosomes contain a functional enzyme activity in vitro that has a potential role in inflammation. Esser et al. (7) demonstrated that the enzymatic capacity of DCs-derived exosomes can convert LTs $\mathrm{A}_{4}$ to other LTs $\left(\mathrm{LTB}_{4}\right.$ and $\left.\mathrm{LTC}_{4}\right)$. Also, they demonstrated that these exosomes induce polymorphonuclear leukocyte migration and granulocyte recruitment to inflammatory sites. Both 5-keto eicosatetraenoic acid (KETE) and $\mathrm{LTB}_{4}$ are potent chemoattractant agents for eosinophils and neutrophils. These molecules are arachidonic acid metabolites produced by MDM-derived exosome enzymatic activity. LTs are pro-inflammatory lipid mediators, which play key roles in the pathogenesis of asthma, allergy, and chronic inflammation.

\section{Exosome from MC- and Basophil-Derived Granules}

Mast cells are granulated cells located in all vascularized tissues, near blood vessels, smooth muscle cells, mucous glands, and hair follicles. They originate from hematopoietic cells and present a large number of granules which primarily store histamine and heparin (56). MCs are key effector cells in Th2- and IgEassociated immune responses and their activation contributes to resistance to parasites and can drive allergic reactions, such as those involved in anaphylaxis and asthma (57).

It has been reported that MCs from both humans and mice can release exosomes (58). The composition of these exosomes is quite heterogeneous and includes factors such as CD13, ribosomal protein 6 kinase, annexin V, Cdc25, phospholipases, heat shock proteins (HSPs), immunological factors (MHC class II), costimulatory factors (CD86, CD40, and CD40L), and adhesion molecules including LFA-1, intercellular adhesion molecules-1 and mRNAs, small RNAs, and miRNAs (56).

Mast cell-derived exosomes can interact with different cell types through immunoregulatory proteins as well as mRNAs and miRNAs (59). Exosomes from MCs provide cell contact signals through CD40 ligands and can stimulate purified B cells to produce IgE through a T-cell independent mechanism (60). Moreover, these exosomes can induce lymphocyte stimulation and proliferation, leading to the production of IL-2, IL-12, and IFN- $\gamma$ (but not IL-4), and Th1 responses (61). Moreover, these exosomes induce the production of pro-inflammatory cytokines such as IL-6 and IL-8 that are released from human airway smooth muscle cells (ASMCs), exacerbating airway inflammation and recruiting inflammatory cells that perpetuate asthmatic symptoms (5). Finally, MC-derived exosomes induce phenotypic 
functional maturation of DCs in vivo and in vitro, improving the immune response (62).

Similar to MCs, basophils are granulated leukocytes derived from granulocyte-monocyte progenitor cells though they exist in a mature state (63). They are present in the circulation in low numbers; however, in a infection and/or inflammation situation, they increase in number and migrate from the bloodstream to infected or inflamed tissue sites. To our knowledge, there are no data related to exosome production by basophils. However, Dvorak (64) reported that these cells contain numerous granules that often have contents resembling exosomes and may be associated with a form of mediator exocytosis.

\section{Eosinophil-Derived Exosomes}

Eosinophils are multifunctional granulocytes implicated in the pathogenesis of inflammatory processes in asthma and helminthic infections. They have been considered to be end-stage cells involved in host defenses against parasites. Eosinophils play a central role in asthma pathogenesis, releasing an array of pro-inflammatory cytokines (IL-2, IL-4, IL-5, IL-10, IL-12, IL-13, IL-16, IL-18, and TGF- $\alpha / \beta$ ), chemokines (RANTES and eotaxin-1), and lipid mediators ( $\mathrm{LTC}_{4}$, platelet-activating factor, thromboxane $\mathrm{B} 2$, and prostaglandins) that orchestrate the processes and symptoms of the disease $(65,66)$. These cells carry a large number of granules in their cytoplasm that contain cytotoxic granule proteins, including major basic protein (MBP), eosinophil cationic protein (ECP), eosinophil-derived neurotoxin (EDN), and eosinophil peroxidase (EPO) $(65,66)$. In addition, several studies have reported that eosinophils can act as APCs, with phagocytic capacity as well as MHC class II and costimulatory molecule expression $(67,68)$.

Although eosinophils are important for allergic and asthmatic processes, no previous studies have been conducted to remark some important aspect of their physiology for asthma and allergy like exosome secretion. To date, there are only two published studies by our group that have characterized eosinophil exosomes and their implications for the pathogenesis of asthma $(8,69)$. Eosinophils secrete nanovesicles that are consistent in size (162 nm diameter, by NanoSight measurement), shape (cup-shape morphology), and composition (presence of CD63, CD9, and ALIX) with exosomes. CD63, CD9, and ALIX proteins indicate that these eosinophil nanovesicles have an endosomal origin from MVBs. Moreover, these exosomes carry eosinophil characteristic proteins, such as MBP and EPO, which could produce tissue damage and asthma exacerbations. Also, exosome secretion is significantly higher in eosinophils from asthmatics than in healthy donors (8).

Regarding their functional effects on eosinophils, we have reported that exosomes from the eosinophils of asthmatic patients induce in these cells a rise in the production of reactive oxygen species. Also, these exosomes increase the migratory capacity in eosinophils, as well as, their adhesion and adhesion molecule expression, which are important processes in asthma. By contrast, eosinophil-derived exosomes from healthy patients do not affect to asthmatic eosinophil functionality (69). Also, we have described the exosome uptake mechanism of eosinophils which involves direct internalization of the whole vesicle, corresponding with one of the two previously described uptake mechanisms (70). Finally, we provided a list of the eosinophil-derived exosome proteins from a pool of both asthmatic patients and healthy volunteers and confirmed the presence of proteins implicated in different cell functions, such as (A) classical eosinophil proteins (MBP, ECP, EDN, and EPO), (B) S100 proteins (S100A8 and S100A9) implicated in antifungal and antibacterial activity, promotion of cytokine and chemokine production, induction of pro-inflammatory responses in monocytes, and chemotactic factors for immune cells (17), (C) HSP with a molecular weight of $70 \mathrm{kDa}$, implicated in protein folding, (D) several integrins (integrin $\alpha_{M}, \beta_{2}$, and $\beta_{3}$ ) related to cell adhesion, (E) periostin and filaggrin, important proteins implicated in asthma pathogenesis, and (F) metabolic enzymes ( $\alpha$-enolase, catalase, and arachidonate 15-lipoxygenase).

\section{Exosomes Released by Lymphocytes}

Lymphocytes have important actions in the immune response. In asthma and allergy, B lymphocytes produce and release IgE against specific allergens or antigens, leading to the degranulation of basophils and MCs, and histamine release. T lymphocytes mediate cytokine changes and shifts to the Th2 phenotype characteristic of asthmatic pathology. Moreover, these cells secrete type 2 cytokines that trigger a series of events including granulocyte migration as well as cytokine and chemokine release by other cell types that drive pro-inflammatory effects and development of the characteristic features of asthma.

Several studies have demonstrated that $\mathrm{T}$ lymphocytes can release exosomes $(71,72)$ and that $\mathrm{CD}^{+} \mathrm{T}$ cells can secrete exosomes with cytolytic properties (4). However, no functional studies have been carried out in asthma or allergy documenting release of exosomes from T cells. By contrast, investigations have shown that exosomes from other cell types can stimulate $\mathrm{T}$ cells and have effects on asthma and allergic responses. Hough et al. (31) compiled several studies of exosome function for immunoregulation in chronic diseases, including asthma. The authors show that exosomes of different origins (B cells, DCs, and BALF) can stimulate activation, proliferation, and Th 2 cytokine production by $\mathrm{CD}^{+} \mathrm{T}$ cells in different ways.

In contrast, a larger number of studies of B-cell-derived exosomes have been presented. After Raposo et al. (52) reported that exosomes carry MHC class II receptors and specifically present antigenic peptides to $\mathrm{T}$ cells, other authors performed further studies of this process. All have concluded that B-cellderived exosomes present MHC class II, costimulatory molecules (CD40, CD80, and CD86) and integrins ( $\beta 1$ and $\beta 2)$ and can induce T-cell responses (73-75). Also, HSPs in the B-cell exosomes are important to the maturation of DCs (76). Admyre et al. (2) published a study related to B-cell-derived exosomes affected T-cell proliferation and Th2 cytokine production. In the study, it was found that the amount of birch peptide (Bet v 1) in exosomes from $\mathrm{B}$ cells needed for induction of proliferation on T cell. Moreover, this exosome-associated peptide induced a Th2 cytokine response resembling that observed in stimulation directly with $\mathrm{B}$ cells, characterized by the release of high levels of IL-4, IL-5, and IL-13 and low levels of IFN- $\gamma$, and tumor necrosis factor (TNF)- $\alpha$. These results indicated an important 
role for exosomes in allergic responses by acting as independent "antigen-presenting structures" for T cells without direct cellto-cell contact. In contrast, exosomes from B cells and other cell types, present in serum or BALF, have been described like allergic tolerogenic particles called tolerosomes $(77,78)$.

\section{Exosomes from Structural Lung Cells in Asthmatic and Allergic Processes}

Several types of anatomical changes are implicated in the characteristic processes involved in asthma progression: airway remodeling, bronchoconstriction, and mucus hypersecretion. The key cellular changes involve ASMCs, goblet cells, and epithelial cells (79). There are no studies addressing exosomes released by ASMCs or goblet cells; however, there are a few studies reporting the effect of exosomes from BALF or produced by other cell types on airway muscle cells.

The ASMCs are important elements in bronchoconstriction and airway remodeling. During asthma progression, hyperplasia and hypertrophy of the airway tissues occur and pro-inflammatory cytokines are released from the structural airway cells.

There are some studies of exosomes acting over airway muscle cells. Xia et al. (5) showed that MCs can stimulate human ASMCs by indirect contact. MCs can adhere to ASMCs via cell adhesion molecule 1 and induce the release of cytokines and chemokine generation by the ASMCs, leading to the recruitment of more MCs, perpetuating the asthma symptoms. This stimulation can occur via exosomes, and depletion of MC-derived exosomes can contribute to reduction of the stimulatory response, although depletion of other soluble factors is also an important factor in this effect. Recently, it has been reported that lipopolysaccharidestimulated neutrophil-derived exosomes affect horse airway smooth muscle remodeling (80). The study shows how horse ASMCs internalized the exosomes from stimulated neutrophils to their cytoplasm and how these exosomes then modulated apoptosis and induced proliferation of the ASMCs, thus contributing to the process of airway remodeling.

The airway epithelium is the primary barrier against external irritants and toxins, such as air pollutants, irritants, allergens, and pathogens. Airway epithelial cells (AECs) constitute the surface layer of the bronchi and alveoli, facing the lumen, and they are in direct contact with the external environment. These cells actively contribute to the establishment and progression of asthma and allergic airway inflammation by orchestrating the inflammatory response to exogenous stimuli, such as allergens and cigarette smoke (6).

Exosomes have been described from different types of AECs. The exosomes show different sizes and shapes, and it has been concluded that their morphology depends on the cell type, and whether there is apical or basal release of the organelles (81). It has also been concluded that these exosomes carry important molecules (mucins and sialic acid) that have been implicated in innate defense mechanisms and that can modulate airway inflammation (16).

Kulshreshtha et al. (6) confirmed the effect of exosomes from bronchial epithelial cells (BECs) on inflammatory processes. Th2 cytokines, principally IL-13, increased the secretion of exosomes from stimulated BECs, and these exosomes could induce monocyte proliferation. Moreover, the cytokine IL-13 modified the composition of these exosomes. Beyond cytokines, other factors such as mechanical stress can stimulate exosome secretion. During episodes of bronchoconstriction in asthmatics, compressive mechanical stress occurs that induces an increased exosome secretion from BECs (79). The effect of BALF-derived exosomes on AECs has been studied by Torregrosa Paredes et al. (15). They reported that exosomes from BALF can stimulate AECs and contribute to inflammation by increasing cytokine (IL-8) and LT $\left(\mathrm{LTC}_{4}\right)$ generation.

Figure 1 depicts a simplified model of the role of exosomes in the interaction between different immune cells in allergic reactions and asthma.

\section{miRNAs AND ASTHMA}

Asthma is a heterogeneous disease; therefore, traditional diagnostic approaches have utilized a classification system in which patients are divided into subgroups according to etiologic diagnosis and treatment. For this purpose, the term endotype was created to distinguish asthmatics not only by their clinical characteristics (phenotype) but also by the pathophysiological characteristics of their disease (82). Currently, to generate new classifications of asthmatic patients, biomarkers of asthma need to be discovered.

The characterization of miRNA expression and its role in asthma has been developed using different approaches. So, miRNA expression in different tissues and cells that are implicated in the pathogenesis of asthma has been studied to determine differential expression between healthy patients and those with active asthmatic disease status. miRNAs that were found to be deregulated in asthmatic samples have been further studied in asthma models, both in vitro and in vivo, to elucidate their functions in asthmatic disease.

Figure 2 shows possible targets of miRNAs in asthma pathogenesis.

\section{miRNAs Expression in Structural Cells: Airway Biopsies, BECs from Epithelial Brushings and Airway Muscle Cells}

Most of the studies of miRNAs in asthma are characterized by being quite heterogeneous. Within the structural airway cells, several cell lines and samples have been studied like nasal biopsies, epithelial cells with different origins or airway muscle cells.

Some studies have employed airway biopsies from asthmatic patients to analyze miRNA expression in whole tissue. Suojalehto et al. $(83,84)$ carried out several studies using nasal biopsies from different populations (allergic and non-allergic rhinitis patients and long-term asthmatic patients) to evaluate miRNAs expression. Study focused on rhinitis pathology (83) showed a higher expression of miR-498, miR-155, and miR-205 in allergic rhinitis population in comparison to control and non-allergic rhinitis subjects. Also, let-7 expression was downregulated in the allergic rhinitis plus asthma group compared to controls and the nonallergic rhinitis group (83). However, some of these upregulated 


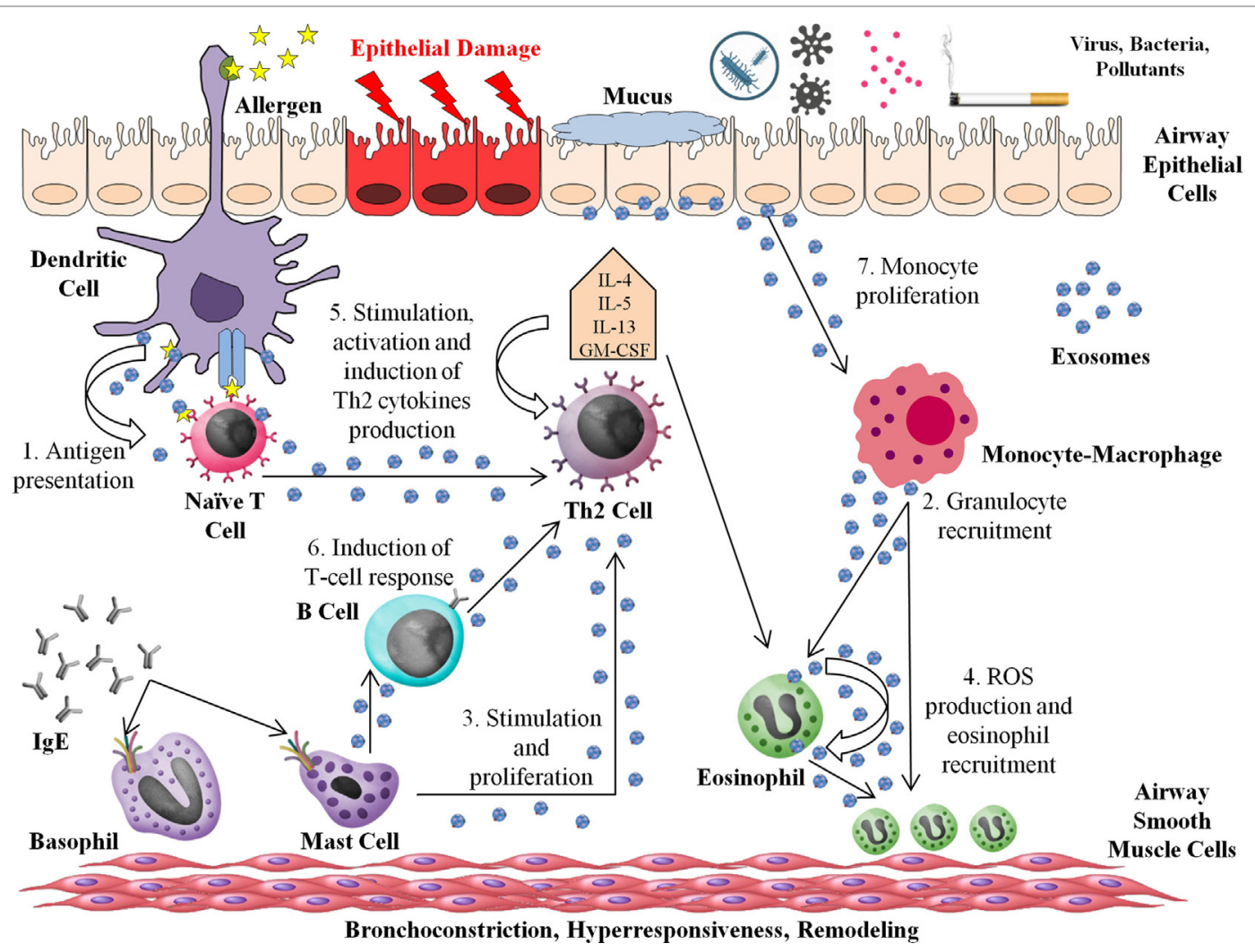

FIGURE 1 | Roles of exosomes in asthma and allergic processes. The entry of the allergen into the airway triggers the Th2 response. Mature dendritic cells (DCs) induce the differentiation of naive CD4+ T cells into CD4+ Th2 cells. The majority of immune cells are able to produce and release exosomes to the Th2 environment, acting in several ways: (1) DC-derived exosomes can stimulate T-cell responses and act as an "antigen-presenting unit." (2) Macrophage-derived exosomes contain functional enzymes that play a potential role in inflammation, synthesizing leukotrienes (LTS) and recruiting granulocytes to the inflammation site. (3) Exosomes from mast cells can stimulate B cells and induce simulation and proliferation of others lymphocytes. (4) Eosinophil-derived exosomes increase the pro-inflammatory capacity of the same or other eosinophils, producing higher quantities of reactive oxygen species and increasing the migration of other eosinophils to the inflammation site. (5) T cells produce exosomes that are able to stimulate, activate, and increase Th2 cytokine release. (6) B-cell-derived exosomes present major histocompatibility complex class II and costimulatory molecules, which are able to induce T-cell responses. (7) Airway epithelial cell-derived exosome carry a range of different molecules implicated in the modulation of inflammation, inducing monocyte proliferation and contributing to increasing cytokine and LT generation. The secretion of exosomes from airway epithelial cells is increased by Th2 cytokines as interleukin-13.

miRNAs were found downregulated in a long-term asthmatic subjects compared to controls (miR-155 and let-7), although miR-498 showed a similar pattern. Also, in the case of long-term asthmatic patients, miR-155 (an upregulated miRNA in rhinitis study) showed a positive correlation with fractional exhaled nitric oxide levels, nasal nitric oxide levels, and IL-13 mRNA levels (84), being a proof of heterogeneous performance of miRNAs.

Using airway biopsies from controls and mild asthmatics before and after corticosteroid therapy, another study showed no differences in miRNA expression patterns by quantitative PCR (qPCR) between these groups, in contrast to previous results. This could be due to the mild asthmatic phenotype. They also observed cell-specific miRNA expression profiles from lung biopsy, demonstrating elevated heterogeneity in these tissue biopsies (85).

Full tissue biopsies are conformed by high cellular heterogeneity, making gene expression profiling difficult to achieve in a cellspecific manner. To address this problem, bronchial epithelial brushings have been employed to analyze miRNAs expression in a single cell type. BECs play important roles in asthma, producing mucus and participating in airway remodeling (86). So, different research groups have focused their attention on this type of cellular population as reference sample in the study of asthma. Solberg et al. (86) showed a differential expression of several miRNAs, including downregulation of the miR-34/449 family, in bronchial epithelial brushings from controls, steroid naive asthmatics (before and after inhaled corticosteroids), and steroidtreated asthmatics, being IL-13 a repressor of this miRNA family (in vitro assays) not affecting their expression the corticosteroid treatment.

Different groups have confirmed the role of some cytokines, such as IL-13, in the modulation of miRNAs. In this way, $\mathrm{Wu}$ et al. (87) observed an effect of IL-13 on the expression of miR-21 and miR-126 that were upregulated in BECs from asthmatics (with or without inhaled corticosteroids treatment). So, when the BECs were cultured with IL-13, a positive correlation between miR-21 and miR-126 expression and IL-13 concentration was found, showing that these miRNAs are upregulated by IL-13. This cytokine is presented in higher levels in asthmatic patients than in 


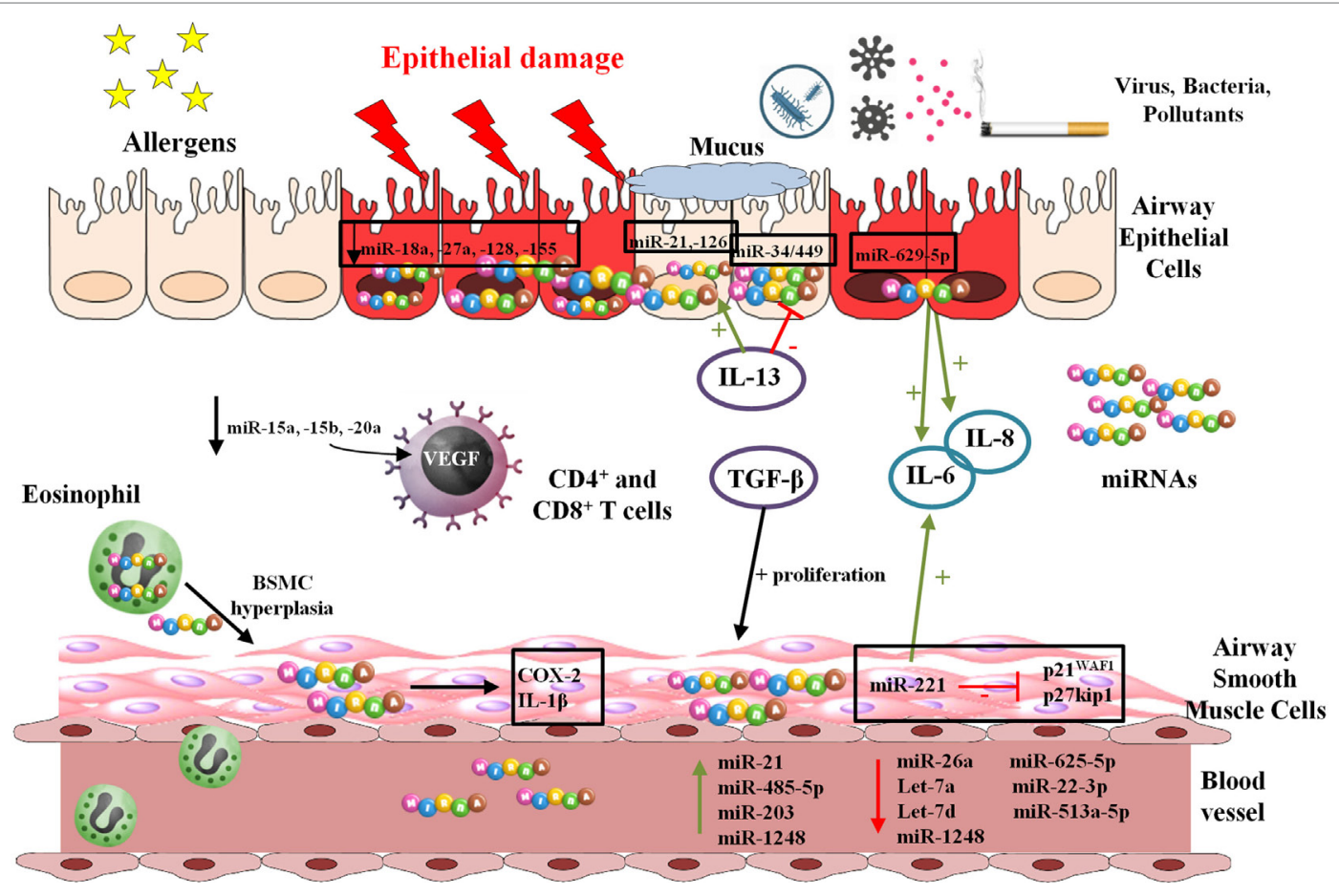

FIGURE 2 | Functions and mechanisms involving microRNAs (miRNAs) in asthma and allergy. miRNAs are preprocessed in the cellular nucleus and completion of processing and maturation occurs in cytoplasm. They are usually delivered inside exosomes by multiple cell types exerting their effects on the own producing cells or on other cellular types.

controls due to its involvement in the development of asthmatic inflammation (87).

A downregulated expression of others miRNAs such as miR-18a, miR-27a, miR-128, and miR-155 has been observed in BECs from bronchial brushings from asthmatic subjects. These miRNAs target pathways of inflammation in silico, being mothers against decapentaplegic homolog 2 (SMAD2) their common target. When a pool of antagomirs for these miRNAs was used, an increase in the levels of IL- 6 and IL-8 was detected (88).

Other groups also employed BECs from healthy controls and asthmatics. Jardim et al. (89) found different expression of miRNAs between asthmatic subjects and those in healthy conditions. One of those deregulated miRNAs was miR-203, which was downregulated in asthmatics. This miRNA targets and regulates the aquaporin gene $A Q P 4$, which is involved in water transport and osmotic regulation of epithelial lung cells (89).

Studies with epithelial cell lines and murine experimental models have revealed the role of another miRNAs, such as miR-570-3p, which are over-expressed in human epithelial cell lines upon stimulation with TNF- $\alpha$. miR-570-3p transfection of AECs increases IL-6, chemokine (C-C motif) ligand 5 (CCL5), and CCL4 production, having a synergistic effect with TNF- $\alpha$ administration. The RNA-binding-protein HuR is a target for miR-570-3p, and at the same time, HuR regulates cytokine expression (90), creating a feedback between them.

Another study in AEC lines showed that $\beta$-catenin protein, which is involved in cell adhesion, was downregulated by transfection with the miR-3162-3p mimic. This result has been confirmed in an ovalbumin (OVA)-induced mouse asthma model, which showed a higher expression of this miRNA and decreased levels of $\beta$-catenin. When anti-miR-3162-3p was administered to these mice, decreasing BALF cell counts and a reduction of airway hyperresponsiveness (AHR) and inflammation, as well as an increase in the $\beta$-catenin levels were found (91).

Airway smooth muscle cells are crucial contributors to airflow obstruction through their hypertrophic and hyperplasic processes. Perry et al. (92) observed that the proliferation of ASMCs from severe asthmatic patients and IL-6 release produced by their stimulation with TGF- $\beta 1$ were mediated through the inhibition of cyclin-dependent kinase inhibitors $\mathrm{p} 21^{\mathrm{WAF} 1}$ and $\mathrm{p} 27^{\mathrm{kipl}}$ by miR221 , deregulating the cell cycle. miR-221 is regulated by TGF- $\beta 1$ and its expression is not altered by corticosteroid treatment. Hu et al. (93) showed that the proliferation of AMSCs is also controlled by miR-10a through suppression of PIK3CA, inhibiting the phosphoinositide 3-kinase (PI3K) pathway, which is involved in cell growth and proliferation. miR-146a and miR-146b were also identified as important miRNAs in asthma pathology, which are highly expressed in stimulated asthmatic ASMCs. They regulate the expression of cyclooxygenase-2, IL-1 $\beta$, and RNA-binding protein $\mathrm{HuR}$ in vitro, leading to the regulation of inflammation (94).

\section{miRNA Expression in Lymphocytes}

Expression pattern of miRNA has been studied in other cell populations involved in asthma besides in structural lung cells. In lymphocytes, miR-15a, miR-15b, and miR-20a are downregulated 
in $\mathrm{CD}^{+} \mathrm{T}$ cells from atopic pediatric patients with asthma, compared to atopic and non-atopic controls. Using reporter and immunoprecipitation assays, it was found that vascular endothelial growth factor A (VEGFA) is targeted by miR-15a. VEGFA is over-expressed in sputum and serum samples of asthmatics and has possible implications in asthma pathogenesis (95). A transcriptomics approach with $\mathrm{CD}^{+}$and $\mathrm{CD} 8^{+} \mathrm{T}$ cells obtained from severe asthmatics, non-severe asthmatics, and healthy controls showed that $\mathrm{CD}^{+} \mathrm{T}$ cells manifested upregulation of the genes is associated with an activated phenotype. qPCR revealed that miR-146a and miR-146b were downregulated in $\mathrm{CD}^{+}$and $\mathrm{CD}^{+} \mathrm{T}$ cells from severe asthmatics compared to non-asthmatic controls, showing that these miRNAs may have a role in $\mathrm{CD}^{+}$ T-cell functions (96).

T helper 2 cytokine production is controlled by phosphatase and tensin homolog, suppressor of cytokine signaling 1 (SOCS1) and deubiquitinase A20. The genes of these proteins are targeted by miR-19a. This miRNA is upregulated in asthmatic Th2 lymphocytes showing a pathophysiological phenomenon occurring in asthma, where those cytokine suppressors are inhibited, and thus inflammation occurs (97).

Additionally, miRNAs from peripheral blood cells are different between asthmatic and healthy subjects. In this way, Dong et al. (98) isolated total RNA from peripheral blood and profiled miRNA expression by microarray and RT-PCR. Their results showed that miR-625-5p, miR-22-3p, and miR-513a-5p were downregulated in peripheral blood samples from asthmatic subjects with dust mite allergy, compared to controls. The targets of these miRNAs ( $C B L, P P A R G C 1 B$, and ESR1) were inversely upregulated in blood RNA. These genes belong to the PI3K-AKT and nuclear factor $\kappa \beta(\mathrm{NF}-\kappa \beta)$ signaling pathways and may be related to the lower concentrations of IFN- $\gamma$, TNF- $\alpha$, IL-12, and IL-10 in plasma obtained from asthmatics (98).

Expression of miR-155-5p was detected as differentially expressed in allergic-airway-diseased, OVA-induced, steroidsensitive mice, decreasing its expression when mice were treated with dexamethasone. Specifically, miR-155-5p is more expressed in lung hematopoietic cells. However, when antagomir for miR155-5p was nasally delivered to mice, no reduction of the disease phenotype or in the expression of target genes was found. This issue was solved by analyzing the anti-miR-155-5p uptake by the different lung cells. Lymphocytes need a higher dose of anti-miR155-5p than monocytes, macrophages, or neutrophils to develop a phenotype, both in vitro as in vivo (99).

\section{miRNA Expression in Body Fluid Samples: Serum, Plasma, Sputum, BALF, and Exhaled Breath Condensate}

Asthma is a complex and multifactorial disease influenced by multiple elements. So, not only the cellular component is important in the development of the characteristics that define it but also the soluble inflammatory microenvironment.

Sputum is currently one of the biofluids with increasing applications in asthma research and diagnosis, principally because it is easily harvested and has a direct relationship with the airways status. Maes et al. (100) studied miRNA expression profiles in sputum from healthy, mild-to-moderate asthmatic, and severe asthmatic subjects. They detected an increased expression of miR-629-3p, miR-223-3p, and miR-142-3p in severe asthmatics. These last two miRNAs showed a trend toward increase in neutrophilic asthmatics, showing a positive correlation between their expression and both neutrophil counts and levels of IL-1 $\beta$, a cytokine involved in inflammatory response. Flow cytometry sorting and in situ hybridization showed that miR-223-3p and miR-142-3p were principally expressed by neutrophils and miR$629-3 p$ by epithelial cells, contributing with this load to miRNAs pool from blood torrent, increasing IL-6 and IL-8 levels.

In the search of representative samples derived directly from the airways, exhaled breath condensate was developed as an alternative to sputum. Exhaled breath condensates from healthy, asthmatic, and chronic obstructive pulmonary disease (COPD) subjects were analyzed by qPCR, showing that some miRNAs are downregulated in asthmatics compared to COPD and control individuals (miR-1248, miR-1291, and let-7a); others are downregulated in both asthmatics and COPD groups (miR328 and miR-21) or downregulated in asthmatic patients than in controls (miR-133a and miR-155). However, all of them share a characteristic: they targeted Th2 mediator genes in silico (101). Also, from this type of sample, exosomes have been isolated and their miRNAs content analyzed, showing 11 miRNAs that were differentially expressed between healthy and asthmatic subjects. Exosomes were isolated from these samples, and it was concluded that exosomes contained the majority of the miRNA content (102).

Another sample from lung that has been widely used to analyze inflammatory status in respiratory diseases like asthma is BALF. In this case, the miRNA profile of exosomes from BALF was also studied in healthy and mild intermittent asthmatics, leading to the conclusion that the expression of 16 miRNAs, including members of the let-7 family and miR-203, was able to differentiate asthmatics from healthy subjects at baseline. After air-pollution exposure, 11 of these 16 miRNAs were able to distinguish asthmatic from controls. Expression of these 16 miRNAs also differentiated atopic patients from non-atopic ones, and their target genes belonged to inflammatory response pathways (103).

Previous samples detailed are obtained through invasive methods and/or require trained staff and special equipment and implicate a high time consumption in clinical routine. To overcome this trouble, less invasive methods are currently under development. One strategy may utilize miRNAs obtained from serum or plasma. They are easily isolated and are resistant to RNase degradation due to they usually get around the organism inside exosomes, making them excellent biomarkers (104).

miRNA-21 is one of the most studied miRNAs, being first identified as a biomarker of B-cell lymphoma (105), and subsequently its expression has also been studied in asthma. Elbehidy et al. (106) showed that miR-21 expression is higher in asthmatic patients than in controls and was also higher in steroidresistant asthmatics compared with steroid-sensitive asthmatics. Moreover, IL-12p35 serum levels were inversely correlated with miR-21 levels, showing a possible role in asthma development through $I L-12 p 35$ repression. Likewise, the ROC curve analysis 
showed that miR-21 expression levels could be used to differentiate asthmatic from healthy children and to monitor the response to corticosteroid treatment (106). Another group has shown that miR-21 expression was elevated in asthmatics' serum compared to controls, although they demonstrated that miR-21 expression in serum does not correlate with serum IgE levels (107).

Profiling miRNAs in serum of children with atopic dermatitis and healthy controls by microarray and qPCR showed an upregulation of miR-483-5p and miR-203 in the serum of the dermatitis cases compared to the controls. Analysis by ROC curves demonstrated that serum levels of both miRNAs differentiated healthy from diseased children and that miR-203 was associated with soluble tumor necrosis factor receptor (sTNFR)
I and sTNFRII levels in serum, both of which were involved in inflammation (108).

Panganiban et al. (109) showed an upregulation of the expression of miR-1248 and a downregulation of miR-26a, let-7a, and let-7d in serum samples from asthmatics compared to controls, and a negative correlation between miR-26a expression and forced expiratory volume (FEV1) in asthmatics. They confirmed that IL- 5 is a target of miR-1248 by using miR-1248 mimics and found that there was bind of this miRNA to the $3^{\prime}$-UTR of IL-5 mRNA (109). This group also described that miR-125b, miR-16, miR-299-5p, miR-126, miR-206, and miR-133b are differentially expressed between asthmatics, allergic rhinitis patients, and controls. Based on these results, they created a random forest

TABLE 1 | MicroRNAs (miRNAs) expression profiling in human samples.

\begin{tabular}{|c|c|c|c|c|}
\hline Sample & Differentially expressed miRNAs & Method & Significance & Reference \\
\hline \multirow[t]{3}{*}{ Airway biopsies } & $\begin{array}{l}\text { miR-498, miR-155, miR-205 (upregulated), let-7 (downregulated) } \\
\text { in allergic rhinitis and asthmatics }\end{array}$ & $\begin{array}{l}\text { Quantitative PCR } \\
\text { (qPCR) }\end{array}$ & Possible disease biomarkers & (83) \\
\hline & $\begin{array}{l}\text { miR-155, let-7 and miR-126 (downregulated), miR-498 } \\
\text { (upregulated) in asthmatic }\end{array}$ & qPCR & $\begin{array}{l}\text { Possible disease biomarkers, associated with } \\
\text { clinical parameters }\end{array}$ & (84) \\
\hline & $\begin{array}{l}\text { Studied } 227 \text { miRNAs, no differences were found in mild } \\
\text { asthmatics }\end{array}$ & qPCR & Cell-specific miRNA expression & (85) \\
\hline \multirow[t]{3}{*}{$\begin{array}{l}\text { Epithelial } \\
\text { brushings }\end{array}$} & $\begin{array}{l}22 \text { miRNAs found, including downregulation of miR-34/449 } \\
\text { families (miR-34c-5p, miR-34b-5p, miR-449a, miR-449b-5p) in } \\
\text { asthmatics }\end{array}$ & $\begin{array}{l}\text { Microarray and } \\
\text { qPCR }\end{array}$ & $\begin{array}{l}\text { Possible disease biomarkers. Interleukin (IL)-13 } \\
\text { represses miR-34/449 family which regulates } \\
\text { differentiation of epithelial cells }\end{array}$ & $(86)$ \\
\hline & $\begin{array}{l}66 \text { miRNAs found, including let-7f, miR-487b, miR-181c } \\
\text { (upregulated) and miR-203 (downregulated) in asthmatics }\end{array}$ & $\begin{array}{l}\text { Microarray and } \\
\text { qPCR }\end{array}$ & $\begin{array}{l}\text { Possible disease biomarkers. AQP } 4 \text { gene is } \\
\text { targeted by miR- } 203\end{array}$ & (89) \\
\hline & miR-21 and miR-126 (upregulated) in asthmatics & qPCR & $\begin{array}{l}\text { Correlation between miR-21 and miR-126 } \\
\text { expression and } \mathrm{IL}-13 \text { concentration in vitro }\end{array}$ & $(87)$ \\
\hline \multirow[t]{2}{*}{ Lymphocytes } & miR-15a, miR-15b, and miR-20a (downregulated) in asthmatics & qPCR & $\begin{array}{l}\text { miR-15a targets vascular endothelial growth } \\
\text { factor } A \text { in } C D 4^{+} T \text { cells }\end{array}$ & (95) \\
\hline & $\begin{array}{l}\text { miR-18a-5p, miR-146a, and miR-146b (downregulated) in } \\
\text { asthmatics }\end{array}$ & $\begin{array}{l}\text { Transcriptomics } \\
\text { and qPCR }\end{array}$ & $\begin{array}{l}\text { miR-146a and miR-146b may have a role in } \\
\text { CD8 }{ }^{+} \text {cell functions }\end{array}$ & $(96)$ \\
\hline Full blood & $\begin{array}{l}\text { miR-625-5p, miR-22-3p, and miR-513a-5p (downregulated) in } \\
\text { asthmatics }\end{array}$ & qPCR & $\begin{array}{l}\text { miR-625-5p, miR-22-3p, and miR-513a-5p } \\
\text { target genes involved in phosphoinositide } \\
\text { 3-kinase-AKT and NF-кB signaling pathways }\end{array}$ & (98) \\
\hline Sputum & $\begin{array}{l}\text { miR-629-3p, miR-223-3p, and miR-142-3p (upregulated) in } \\
\text { severe asthmatics }\end{array}$ & $\begin{array}{l}\text { Microarray and } \\
\text { qPCR }\end{array}$ & $\begin{array}{l}\text { miR-223-3p and miR-142-3p are expressed } \\
\text { by neutrophils. miR-629-3p is expressed by } \\
\text { epithelial cells and regulates IL- } 6 \text { and IL-8 }\end{array}$ & $(100)$ \\
\hline \multirow{2}{*}{$\begin{array}{l}\text { Exhaled breath } \\
\text { condensate }\end{array}$} & miR-133a and miR-155 (downregulated) in asthmatics & qPCR & Possible disease biomarkers & $(101)$ \\
\hline & $\begin{array}{l}\text { miR-649, miR-1264, miR-2861, miR-574-5p (upregulated) and } \\
\text { miR-453, miR-4256, miR-556-5p (downregulated) in asthmatic }\end{array}$ & $\begin{array}{l}\text { miRNome and } \\
\text { qPCR }\end{array}$ & Possible disease biomarkers & $(102)$ \\
\hline $\begin{array}{l}\text { Bronchoalveolar } \\
\text { lavage fluid } \\
\text { exosomes }\end{array}$ & $\begin{array}{l}\text { Let-7a, miRNA-21, miRNA-24, miR-26a, miRNA-99a, } \\
\text { miRNA-200c (downregulated), and miRNA-658, miRNA-1268 } \\
\text { (upregulated) in asthmatics }\end{array}$ & $\begin{array}{l}\text { Microarray and } \\
\text { qPCR }\end{array}$ & Possible disease biomarkers & $(103)$ \\
\hline Plasma & $\begin{array}{l}\text { miR-125b (downregulated) and miR-16, miR-299-5p, miR-126, } \\
\text { miR-206, miR-133b (upregulated) in asthmatics }\end{array}$ & $\begin{array}{l}\text { Microarray and } \\
\text { qPCR }\end{array}$ & Possible disease biomarkers & $(110)$ \\
\hline \multirow[t]{4}{*}{ Serum } & $\begin{array}{l}\text { miR-21 (upregulated) in asthmatic compared to controls and } \\
\text { upregulated in steroid-resistant asthmatics compared with } \\
\text { steroid-sensitive asthmatics }\end{array}$ & qPCR & $\begin{array}{l}\text { Possible disease biomarker. miR-21 targets } \\
\text { IL-12p35 }\end{array}$ & $(106)$ \\
\hline & miR-21 upregulated in asthmatics & qPCR & $\begin{array}{l}\text { Possible disease biomarker. miR-21 does not } \\
\text { correlate with serum lgE levels }\end{array}$ & $(107)$ \\
\hline & $\begin{array}{l}\text { miR-483-5p and miR-203 upregulated in atopic dermatitis } \\
\text { compared to controls }\end{array}$ & $\begin{array}{l}\text { Microarray and } \\
\text { qPCR }\end{array}$ & $\begin{array}{l}\text { Possible disease biomarkers. miR-203 is } \\
\text { associated with soluble tumor necrosis factor } \\
\text { receptor (sTNFRI) and sTNFRII levels }\end{array}$ & $(108)$ \\
\hline & $\begin{array}{l}\text { miR-1248 (upregulated), miR-26a, let-7a, and let-7d } \\
\text { (downregulated) in asthmatics }\end{array}$ & qPCR & $\begin{array}{l}\text { Possible disease biomarkers. IL- } 5 \text { is target of } \\
\text { miR-1248. Correlation between miR-26a and } \\
\text { FEV1\% }\end{array}$ & $(109)$ \\
\hline
\end{tabular}


model in which the expression of these six miRNAs was able to determine whether a subject was healthy or had disease status with 73 of 79 correct predictions (92.4\%; AUC =9.7). These miRNAs also targeted genes of pathways implicated in immune response and inflammation (110).

An overview of miRNA expression profiling in human samples and their possible roles and function in relation to asthma and allergy is summarized in Tables $\mathbf{1}$ and 2, respectively.

\section{EXOSOMES AND MIRNAS: BIOMARKERS AND POTENTIAL THERAPEUTIC TOOLS}

The recent knowledge of exosomes and miRNA structure and function has allowed that both can be used as molecular biomarkers for diagnostic and prognostic purposes and raised the possibility of developing potential therapeutic tools (111). Detection of miRNAs in human body fluids (including serum, plasma, urine, and saliva) has led to studies focused on the development of miRNA tests as disease biomarkers. Moreover, these non-coding RNAs sequences are usually transported in microparticles and exosomes, which prevents their degradation, and this bestows an advantage to utilize them for these studies (112). In particular, cancer research is a field in which miRNAs and exosomes have become relevant, for use as biomarkers as well as therapeutic tools (113-120). In addition, there is an increased interest in different pathologies (121-127), including pulmonary diseases $(128,129)$.

So, asthma is one of the medicine field in which modulation of miRNA expression as a therapeutic approach is being explored. Inhibition of miR-126 has been tried in mouse models of asthma, showing that regulation of this miRNA targets toll-like receptor 4 (TLR4) through upregulation of transcription factor PU.1 and upregulation of target of Myb protein 1, blocking IL-1 $\beta$ and TNF$\alpha$ and thus inhibiting the asthmatic inflammation phenotype $(130,131)$. Another group confirmed that the modulation of miRNA expression can be a potential treatment. OVA-induced mice were treated with an anti-miR-221, causing a reduction in cell infiltration and eosinophils in BALF (132).

Let-7 is one of the most studied miRNAs in asthma. Kumar et al. (133) showed a positive binding of let-7 to IL-13 3'-UTR mRNA by luciferase reporter assays in vitro. Also, when $\mathrm{T}$ cells from human PBMCs were cultured under T-polarizing conditions and transfected with let-7 family miRNAs, a reduction in IL-13 production was observed. In vivo, they found less expression of let-7 in OVA-induced asthma mice model, and when let-7 mimic was delivered into these mice, a reduction of IL-13 and other

TABLE 2 | MicroRNAs (miRNAs) function in asthma.

\begin{tabular}{|c|c|c|c|c|}
\hline Study model & miRNA & Gene target & Significance & Reference \\
\hline Airway smooth muscle cells (ASMCs) & miR-221 & $\mathrm{p} 21^{\text {WAF1 }}$ and p27 $7^{\mathrm{kip} 1}$ & Regulation of cell proliferation & $(92)$ \\
\hline ASMCs & $\mathrm{miR}-10 \mathrm{a}$ & PIK3CA & Regulation of cell growth and proliferation & $(93)$ \\
\hline ASMCs & $\begin{array}{l}\operatorname{miR}-146 a \text { and } \\
\operatorname{miR}-146 b\end{array}$ & Cyclooxygenase-2, IL-1 $\beta$, HuR & Regulation of cytokine expression and inflammation & (94) \\
\hline Airway epithelial cells (AECs) & $\operatorname{miR}-570-3 p$ & HuR & Regulation of cytokine expression & (90) \\
\hline $\begin{array}{l}\text { AECs/ovalbumin (OVA)-induced } \\
\text { asthma mouse model }\end{array}$ & miR-3162-3p & $\beta$-catenin & Regulation of cell adhesion, and inflammation & $(91)$ \\
\hline Bronchial epithelial cells (BECs) & $\begin{array}{l}\text { miR-18a, miR-27a, } \\
\text { miR-128 and } \\
\text { miR-155 }\end{array}$ & SMAD2 & Regulation of cytokine expression & (88) \\
\hline BECs & miR-203 & AQP4 (non-validated) & Osmotic regulation & (89) \\
\hline BECs & $\mathrm{miR}-449$ & NOTCH1 & Airway mucous metaplasia & (86) \\
\hline BECs & miR-629-3p & IL-6 and IL-8 (non-validated) & Regulation of cytokine expression & $(100)$ \\
\hline OVA-induced asthma mouse model & miR-155-5p & ACVR2A, TAB 2 (non-validated) & Anti-miR-155-5p uptake depends on cell type & (99) \\
\hline $\begin{array}{l}\text { Th2 lymphocytes/OVA-induced } \\
\text { asthma mouse model }\end{array}$ & miR-19a & $\begin{array}{l}\text { Phosphatase and tensin homolog, } \\
\text { SOCS1, A20 }\end{array}$ & Regulation of cytokine expression and inflammation & $(97)$ \\
\hline OVA-induced asthma mouse model & miR-126 & PU.1, target of Myb protein 1 & Regulation of inflammation & $(130,131)$ \\
\hline OVA-induced asthma mouse model & anti-miR-221 & & Regulation of inflammation & $(132)$ \\
\hline $\begin{array}{l}\text { CD4+ } T \text { cells/OVA-induced asthma } \\
\text { mouse model }\end{array}$ & Let-7 & $\mathrm{IL}-13$ & Regulation of cytokine expression and inflammation & $(133,134)$ \\
\hline $\mathrm{CD}^{+}{ }^{+} \mathrm{T}$ cells & $\operatorname{miR}-15 a$ & Vascular endothelial growth factor A & Regulation of angiogenesis, cell migration & $(95)$ \\
\hline $\begin{array}{l}\text { Jurkat T cells/peripheral blood } \\
\text { mononuclear cells }\end{array}$ & $\operatorname{miR}-1248$ & IL-5 & Regulation of inflammation & $(109)$ \\
\hline Blood total RNA & $\begin{array}{l}\text { miR-625-5p, miR-22- } \\
\text { 3p, miR-513a-5p }\end{array}$ & $\begin{array}{l}\text { CBL, PPARGC1B, and ESR1 } \\
\text { (non-validated) }\end{array}$ & Regulation of cytokine expression & (98) \\
\hline Serum RNA & miR-21 & IL-12p35 (non-validated) & Regulation of cytokine expression & $(106)$ \\
\hline Serum RNA & $\operatorname{miR}-203$ & $\begin{array}{l}\text { Soluble tumor necrosis factor } \\
\text { receptor (sTNFRI) and sTNFRII } \\
\text { (non-validated) }\end{array}$ & Regulation of cytokine expression & $(108)$ \\
\hline
\end{tabular}


asthma features such as cell infiltration and AHR were observed (133). Polikepahad et al. (134) also described the let-7 family as strongly expressed in lungs, independently of allergen exposure. When they analyzed IL-13 mRNA and let-7 expression in naive $\mathrm{CD}^{+}{ }^{+} \mathrm{T}$ cells, IL-13 was upregulated and let-7 was downregulated. Administration of anti-let-7 before OVA challenge in OVA mice models decreased IL-13 levels, and they observed a reduced AHR, cell infiltration, and mucus production (134).

These results demonstrate that more research is needed to elucidate miRNA modulation as a therapeutic target, although initial studies show promising potential. Moreover, another field of research is focused on interventions over exosomes. So, diverse agents could act directly or indirectly on exosome biogenesis, secretion, and function. This exosome modulation opens a new way in future therapeutic approach to control different mechanisms implicated in asthma development (69).

\section{CONCLUSION}

Exosomes and miRNAs are the most important areas of biomedical research emerging in last years. Both components of cellular machinery are rising in all fields of medicine as powerful potential tools with relevant roles in prophylactic, diagnostic, and possible new therapeutic approaches. The potential use of exosomes and miRNAs is being demonstrated in multiple pathologies. In respiratory field, specifically asthma pathology, exosomes and miRNAs from several cell types contribute, in a different manner depending of context, to worsen or improve symptoms of pathology. Their capacities to get around other areas convert

\section{REFERENCES}

1. Lee RC, Feinbaum RL, Ambros V. The C. elegans heterochronic gene lin-4 encodes small RNAs with antisense complementarity to lin-14. Cell (1993) 75(5):843-54. doi:10.1016/0092-8674(93)90529-Y

2. Admyre C, Bohle B, Johansson SM, Focke-Tejkl M, Valenta R, Scheynius A, et al. B cell-derived exosomes can present allergen peptides and activate allergen-specific T cells to proliferate and produce TH2-like cytokines. J Allergy Clin Immunol (2007) 120(6):1418-24. doi:10.1016/j.jaci.2007.06.040

3. Vallhov H, Gutzeit C, Hultenby K, Valenta R, Grönlund H, Scheynius A. Dendritic cell-derived exosomes carry the major cat allergen Fel $\mathrm{d} 1$ and induce an allergic immune response. Allergy (2015) 70(12):1651-5. doi:10.1111/ all.12701

4. Blanchard N, Lankar D, Faure F, Regnault A, Dumont C, Raposo G, et al. TCR activation of human T cells induces the production of exosomes bearing the TCR/CD3/zeta complex. J Immunol (2002) 168(7):3235-41. doi:10.4049/ jimmunol.168.7.3235

5. Xia YC, Harris T, Stewart AG, Mackay GA. Secreted factors from human mast cells trigger inflammatory cytokine production by human airway smooth muscle cells. Int Arch Allergy Immunol (2013) 160(1):75-85. doi:10.1159/000339697

6. Kulshreshtha A, Ahmad T, Agrawal A, Ghosh B. Proinflammatory role of epithelial cell-derived exosomes in allergic airway inflammation. J Allergy Clin Immunol (2013) 131(4):1194-203, 1203.e1-14. doi:10.1016/j.jaci.2012.12.1565

7. Esser J, Gehrmann U, D’Alexandri FL, Hidalgo-Estévez AM, Wheelock CE, Scheynius A, et al. Exosomes from human macrophages and dendritic cells contain enzymes for leukotriene biosynthesis and promote granulocyte migration. J Allergy Clin Immunol (2010) 126(5):1032-40, 1040.e1-4. doi:10.1016/j. jaci.2010.06.039

8. Mazzeo C, Cañas JA, Zafra MP, Rojas Marco A, Fernández-Nieto M, Sanz V, et al. Exosome secretion by eosinophils: a possible role in asthma pathogenesis. J Allergy Clin Immunol (2015) 135(6):1603-13. doi:10.1016/j.jaci.2014.11.026 them in an exceptional potential tool to modulate pathologic processes. As we have previously detailed, both structural lung cells and effector cells contribute to exosomes pool and miRNAs content that characterize the inflammatory microenvironment that determine the clinical symptoms and severity of asthma and allergic disease.

However, there are still many unknowns that need to be solved. Which are the elements that specifically modulate each miRNA in each context? Which stimulus affect to content of exosomes? Could we regulate the quantity and composition of these exosomes? So, exosomes and miRNAs could be new and crucial elements in effort of traslacional research to establish a "signature" that allows a better diagnostic, prophylactic, or therapeutic approach, although a better understanding of the impact and functional mechanisms of these elements is necessary.

\section{AUTHOR CONTRIBUTIONS}

VP conceived the manuscript and JC, BS, and JR-M contributed to the writing of the manuscript and all approved its final content.

\section{ACKNOWLEDGMENTS}

The authors acknowledge Oliver Shaw, English editor of IIS-FJD, for his revision and editing in English. This study was supported by Fondo de Investigación Sanitaria-FIS [PI15/00803]; CIBER de Enfermedades Respiratorias (CIBERES), a Carlos III Institute of Health Initiative; Conchita Rábago Foundation (FCR); and FEDER founds.

9. Rieu S, Géminard C, Rabesandratana H, Sainte-Marie J, Vidal M. Exosomes released during reticulocyte maturation bind to fibronectin via integrin alpha4beta1. Eur J Biochem (2000) 267(2):583-90. doi:10.1046/j.1432-1327. 2000.01036.x

10. Heijnen HF, Schiel AE, Fijnheer R, Geuze HJ, Sixma JJ. Activated platelets release two types of membrane vesicles: microvesicles by surface shedding and exosomes derived from exocytosis of multivesicular bodies and alphagranules. Blood (1999) 94(11):3791-9.

11. Potolicchio I, Carven GJ, Xu X, Stipp C, Riese RJ, Stern LJ, et al. Proteomic analysis of microglia-derived exosomes: metabolic role of the aminopeptidase CD13 in neuropeptide catabolism. J Immunol (2005) 175(4):2237-43. doi:10.4049/jimmunol.175.4.2237

12. Wolfers J, Lozier A, Raposo G, Regnault A, Théry C, Masurier C, et al. Tumorderived exosomes are a source of shared tumor rejection antigens for CTL cross-priming. Nat Med (2001) 7(3):297-303. doi:10.1038/85438

13. Gallo A, Tandon M, Alevizos I, Illei GG. The majority of microRNAs detectable in serum and saliva is concentrated in exosomes. PLoS One (2012) 7(3):e30679. doi:10.1371/journal.pone.0030679

14. Admyre C, Johansson SM, Qazi KR, Filén J-J, Lahesmaa R, Norman M, et al. Exosomes with immune modulatory features are present in human breast milk. J Immunol (2007) 179(3):1969-78. doi:10.4049/jimmunol.179.3.1969

15. Torregrosa Paredes P, Esser J, Admyre C, Nord M, Rahman QK, Lukic A, et al. Bronchoalveolar lavage fluid exosomes contribute to cytokine and leukotriene production in allergic asthma. Allergy (2012) 67(7):911-9. doi:10.1111/j.1398-9995.2012.02835.x

16. Kesimer M, Scull M, Brighton B, DeMaria G, Burns K, O’Neal W, et al. Characterization of exosome-like vesicles released from human tracheobronchial ciliated epithelium: a possible role in innate defense. FASEB J (2009) 23(6):1858-68. doi:10.1096/fi.08-119131

17. Lässer C, O'Neil SE, Shelke GV, Sihlbom C, Hansson SF, Gho YS, et al. Exosomes in the nose induce immune cell trafficking and harbour an altered 
protein cargo in chronic airway inflammation. J Transl Med (2016) 14(1):181. doi:10.1186/s12967-016-0927-4

18. Simhadri VR, Reiners KS, Hansen HP, Topolar D, Simhadri VL, Nohroudi K, et al. Dendritic cells release HLA-B-associated transcript-3 positive exosomes to regulate natural killer function. PLoS One (2008) 3(10):e3377. doi:10.1371/ journal.pone.0003377

19. Azevedo LCP, Janiszewski M, Pontieri V, Pedro Mde A, Bassi E, Tucci PJ, et al. Platelet-derived exosomes from septic shock patients induce myocardial dysfunction. Crit Care (2007) 11(6):R120. doi:10.1186/cc6176

20. Masyuk AI, Masyuk TV, LaRusso NF. Exosomes in the pathogenesis, diagnostics and therapeutics of liver diseases. J Hepatol (2013) 59(3):621-5. doi:10.1016/j.jhep.2013.03.028

21. Vella LJ, Sharples RA, Nisbet RM, Cappai R, Hill AF. The role of exosomes in the processing of proteins associated with neurodegenerative diseases. Eur Biophys J (2008) 37(3):323-32. doi:10.1016/j.jhep.2013.03.028

22. Rak J, Guha A. Extracellular vesicles - vehicles that spread cancer genes. Bioessays (2012) 34(6):489-97. doi:10.1002/bies.201100169

23. Record M, Carayon K, Poirot M, Silvente-Poirot S. Exosomes as new vesicular lipid transporters involved in cell-cell communication and various pathophysiologies. Biochim Biophys Acta (2014) 1841(1):108-20. doi:10.1016/j. bbalip.2013.10.004

24. Subra C, Grand D, Laulagnier K, Stella A, Lambeau G, Paillasse M, et al. Exosomes account for vesicle-mediated transcellular transport of activatable phospholipases and prostaglandins. JLipid Res (2010) 51(8):2105-20. doi:10.1194/jlr.M003657

25. Keerthikumar S, Chisanga D, Ariyaratne D, Al Saffar H, Anand S, Zhao K, et al. ExoCarta: a web-based compendium of exosomal cargo. J Mol Biol (2016) 428(4):688-92. doi:10.1016/j.jmb.2015.09.019

26. Théry C, Ostrowski M, Segura E. Membrane vesicles as conveyors of immune responses. Nat Rev Immunol (2009) 9(8):581-93. doi:10.1038/nri2567

27. Pan Q, Ramakrishnaiah V, Henry S, Fouraschen S, de Ruiter PE, Kwekkeboom J, et al. Hepatic cell-to-cell transmission of small silencing RNA can extend the therapeutic reach of RNA interference (RNAi). Gut (2012) 61(9):1330-9. doi:10.1136/gutjnl-2011-300449

28. Zhuang X, Xiang X, Grizzle W, Sun D, Zhang S, Axtell RC, et al. Treatment of brain inflammatory diseases by delivering exosome encapsulated anti-inflammatory drugs from the nasal region to the brain. Mol Ther (2011) 19(10):1769-79. doi:10.1038/mt.2011.164

29. Tian Y, Li S, Song J, Ji T, Zhu M, Anderson GJ, et al. A doxorubicin delivery platform using engineered natural membrane vesicle exosomes for targeted tumor therapy. Biomaterials (2014) 35(7):2383-90. doi:10.1016/j. biomaterials.2013.11.083

30. Tacar O, Sriamornsak P, Dass CR. Doxorubicin: an update on anticancer molecular action, toxicity and novel drug delivery systems. J Pharm Pharmacol (2013) 65(2):157-70. doi:10.1111/j.2042-7158.2012.01567.x

31. Hough KP, Chanda D, Duncan SR, Thannickal VJ, Deshane JS. Exosomes in immunoregulation of chronic lung diseases. Allergy (2016) 72(4):534-44. doi:10.1111/all.13086

32. Aline F, Bout D, Amigorena S, Roingeard P, Dimier-Poisson I. Toxoplasma gondii antigen-pulsed-dendritic cell-derived exosomes induce a protective immune response against T. gondii infection. Infect Immun (2004) 72(7):4127-37. doi:10.1128/IAI.72.7.4127-4137.2004

33. Fujita Y, Yoshioka Y, Ito S, Araya J, Kuwano K, Ochiya T. Intercellular communication by extracellular vesicles and their microRNAs in asthma. Clin Ther (2014) 36(6):873-81. doi:10.1016/j.clinthera.2014.05.006

34. Kim VN. MicroRNA biogenesis: coordinated cropping and dicing. Nat Rev Mol Cell Biol (2005) 6(5):376-85. doi:10.1038/nrm1644

35. Kozomara A, Griffiths-Jones S. miRBase: annotating high confidence microRNAs using deep sequencing data. Nucleic Acids Res (2014) 42(Database issue):D68-73. doi:10.1093/nar/gkt1181

36. Ibáñez-Ventoso C, Vora M, Driscoll M. Sequence relationships among $C$. elegans, D. melanogaster and human microRNAs highlight the extensive conservation of microRNAs in biology. PLoS One (2008) 3(7):e2818. doi:10.1371/ journal.pone.0002818

37. Kim VN, Han J, Siomi MC. Biogenesis of small RNAs in animals. Nat Rev Mol Cell Biol (2009) 10(2):126-39. doi:10.1038/nrm2632

38. Du T, Zamore PD. Beginning to understand microRNA function. Cell Res (2007) 17(8):661-3. doi:10.1038/cr.2007.67
39. Lim LP, Glasner ME, Yekta S, Burge CB, Bartel DP. Vertebrate microRNA genes. Science (2003) 299(5612):1540. doi:10.1126/science.1080372

40. Bartel DP. MicroRNAs: genomics, biogenesis, mechanism, and function. Cell (2004) 116(2):281-97. doi:10.1016/S0092-8674(04)00045-5

41. Engels BM, Hutvagner G. Principles and effects of microRNA-mediated post-transcriptional gene regulation. Oncogene (2006) 25(46):6163-9. doi:10.1038/sj.onc.1209909

42. Pillai RS, Bhattacharyya SN, Filipowicz W. Repression of protein synthesis by miRNAs: how many mechanisms? Trends Cell Biol (2007) 17(3):118-26. doi:10.1016/j.tcb.2006.12.007

43. Berezikov E. Evolution of microRNA diversity and regulation in animals. Nat Rev Genet (2011) 12(12):846-60. doi:10.1038/nrg3079

44. Thomson DW, Bracken CP, Goodall GJ. Experimental strategies for microRNA target identification. Nucleic Acids Res (2011) 39(16):6845-53. doi:10.1093/nar/gkr330

45. Rajewsky N. microRNA target predictions in animals. Nat Genet (2006) 38:S8-13. doi:10.1038/ng1798

46. Thomas M, Lieberman J, Lal A. Desperately seeking microRNA targets. Nat Struct Mol Biol (2010) 17(10):1169-74. doi:10.1038/nsmb.1921

47. Singh NK. miRNAs target databases: developmental methods and target identification techniques with functional annotations. Cell Mol Life Sci (2017) 74(12):2239-61. doi:10.1007/s00018-017-2469-1

48. Ahmadi H, Ahmadi A, Azimzadeh-Jamalkandi S, Shoorehdeli MA, Salehzadeh-Yazdi A, Bidkhori G, et al. HomoTarget: a new algorithm for prediction of microRNA targets in Homo sapiens. Genomics (2013) 101(2): 94-100. doi:10.1016/j.ygeno.2012.11.005

49. Reyes-Herrera PH, Ficarra E. One decade of development and evolution of microRNA target prediction algorithms. Genomics Proteomics Bioinformatics (2012) 10(5):254-63. doi:10.1016/j.gpb.2012.10.001

50. Zitvogel L, Mayordomo JI, Tjandrawan T, DeLeo AB, Clarke MR, Lotze MT, et al. Therapy of murine tumors with tumor peptide-pulsed dendritic cells: dependence on $\mathrm{T}$ cells, B7 costimulation, and $\mathrm{T}$ helper cell 1-associated cytokines. J Exp Med (1996) 183(1):87-97. doi:10.1084/jem.183.1.87

51. Théry C, Duban L, Segura E, Véron P, Lantz O, Amigorena S. Indirect activation of naïve CD4+ T cells by dendritic cell-derived exosomes. Nat Immunol (2002) 3(12):1156-62. doi:10.1038/ni854

52. Raposo G, Nijman HW, Stoorvogel W, Liejendekker R, Harding CV, Melief CJ, et al. B lymphocytes secrete antigen-presenting vesicles. J Exp Med (1996) 183(3):1161-72. doi:10.1084/jem.183.3.1161

53. Admyre C, Grunewald J, Thyberg J, Gripenbäck S, Tornling G, Eklund A, et al. Exosomes with major histocompatibility complex class II and co-stimulatory molecules are present in human BAL fluid. Eur Respir J (2003) 22(4):578-83. doi:10.1183/09031936.03.00041703

54. Ostrowski M, Carmo NB, Krumeich S, Fanget I, Raposo G, Savina A, et al. Rab27a and Rab27b control different steps of the exosome secretion pathway. Nat Cell Biol (2010) 12(1):19-30; sup 1-13. doi:10.1038/ncb2000

55. Ismail N, Wang Y, Dakhlallah D, Moldovan L, Agarwal K, Batte K, et al. Macrophage microvesicles induce macrophage differentiation and miR-223 transfer. Blood (2013) 121(6):984-95. doi:10.1182/blood-2011-08-374793

56. Merluzzi S, Betto E, Ceccaroni AA, Magris R, Giunta M, Mion F. Mast cells, basophils and B cell connection network. Mol Immunol (2015) 63(1):94-103. doi:10.1016/j.molimm.2014.02.016

57. Galli SJ, Nakae S, Tsai M. Mast cells in the development of adaptive immune responses. Nat Immunol (2005) 6(2):135-42. doi:10.1038/ni1158

58. Raposo G, Tenza D, Mecheri S, Peronet R, Bonnerot C, Desaymard C. Accumulation of major histocompatibility complex class II molecules in mast cell secretory granules and their release upon degranulation. Mol Biol Cell (1997) 8(12):2631-45. doi:10.1091/mbc.8.12.2631

59. Valadi H, Ekström K, Bossios A, Sjöstrand M, Lee JJ, Lötvall JO. Exosomemediated transfer of mRNAs and microRNAs is a novel mechanism of genetic exchange between cells. Nat Cell Biol (2007) 9(6):654-9. doi:10.1038/ncb1596

60. Gauchat JF, Henchoz S, Mazzei G, Aubry JP, Brunner T, Blasey H, et al. Induction of human IgE synthesis in B cells by mast cells and basophils. Nature (1993) 365(6444):340-3. doi:10.1038/365340a0

61. Tkaczyk C, Villa I, Peronet R, David B, Chouaib S, Mécheri S. In vitro and in vivo immunostimulatory potential of bone marrow-derived mast cells on B- and T-lymphocyte activation. J Allergy Clin Immunol (2000) 105:134-42. doi:10.1016/S0091-6749(00)90188-X 
62. Skokos D, Botros HG, Demeure C, Morin J, Peronet R, Birkenmeier G, et al. Mast cell-derived exosomes induce phenotypic and functional maturation of dendritic cells and elicit specific immune responses in vivo. J Immunol (2003) 170(6):3037-45. doi:10.4049/jimmunol.170.6.3037

63. Stone KD, Prussin C, Metcalfe DD. IgE, mast cells, basophils, and eosinophils. J Allergy Clin Immunol (2010) 125(2 Suppl 2):S73-80. doi:10.1016/j. jaci.2009.11.017

64. Dvorak AM. Degranulation and recovery from degranulation of basophils and mast cells. Chem Immunol Allergy (2005) 85:205-51. doi:10.1159/000086519

65. Hogan SP, Rosenberg HF, Moqbel R, Phipps S, Foster PS, Lacy P, et al. Eosinophils: biological properties and role in health and disease. Clin Exp Allergy (2008) 38(5):709-50. doi:10.1111/j.1365-2222.2008.02958.x

66. Varricchi G, Bagnasco D, Borriello F, Heffler E, Canonica GW. Interleukin-5 pathway inhibition in the treatment of eosinophilic respiratory disorders. Curr Opin Allergy Clin Immunol (2016) 16(2):186-200. doi:10.1097/ ACI.0000000000000251

67. Del Pozo V, De Andrés B, Martín E, Cárdaba B, Fernández JC, Gallardo S, et al. Eosinophil as antigen-presenting cell: activation of $\mathrm{T}$ cell clones and $\mathrm{T}$ cell hybridoma by eosinophils after antigen processing. Eur J Immunol (1992) 22(7):1919-25. doi:10.1002/eji.1830220736

68. Shi HZ. Eosinophils function as antigen-presenting cells. J Leukoc Biol (2004) 76(3):520-7. doi:10.1189/jlb.0404228

69. Cañas JA, Sastre B, Mazzeo C, Fernández-Nieto M, Rodrigo-Muñoz JM, González-Guerra A, et al. Exosomes from eosinophils autoregulate and promote eosinophil functions. J Leukoc Biol (2017) 101(5):1191-9. doi:10.1189/ jlb.3AB0516-233RR

70. Camussi G, Deregibus MC, Bruno S, Cantaluppi V, Biancone L. Exosomes/ microvesicles as a mechanism of cell-to-cell communication. Kidney Int (2010) 78(9):838-48. doi:10.1038/ki.2010.278

71. Peters PJ, Geuze HJ, Van der Donk HA, Slot JW, Griffith JM, Stam NJ, et al. Molecules relevant for $\mathrm{T}$ cell-target cell interaction are present in cytolytic granules of human T lymphocytes. Eur J Immunol (1989) 19(8):1469-75. doi:10.1002/eji.1830190819

72. Peters PJ, Borst J, Oorschot V, Fukuda M, Krähenbühl O, Tschopp J, et al. Cytotoxic T lymphocyte granules are secretory lysosomes, containing both perforin and granzymes. J Exp Med (1991) 173(5):1099-109. doi:10.1084/ jem.173.5.1099

73. Buschow SI, van Balkom BWM, Aalberts M, Heck AJR, Wauben M, Stoorvogel W. MHC class II-associated proteins in B-cell exosomes and potential functional implications for exosome biogenesis. Immunol Cell Biol (2010) 88(8):851-6. doi:10.1038/icb.2010.64

74. Muntasell A, Berger AC, Roche PA. T cell-induced secretion of MHC class II-peptide complexes on B cell exosomes. EMBO J (2007) 26(19):4263-72. doi:10.1038/sj.emboj.7601842

75. Clayton A, Turkes A, Dewitt S, Steadman R, Mason MD, Hallett MB. Adhesion and signaling by B cell-derived exosomes: the role of integrins. FASEB J (2004) 18(9):977-9. doi:10.1096/fi.03-1094fje

76. Clayton A, Turkes A, Navabi H, Mason MD, Tabi Z. Induction of heat shock proteins in B-cell exosomes. J Cell Sci (2005) 118(16):3631-8. doi:10.1242/ jcs.02494

77. Prado N, Marazuela EG, Segura E, Fernández-García H, Villalba M, Théry C, et al. Exosomes from bronchoalveolar fluid of tolerized mice prevent allergic reaction.J Immunol(2008) 181(2):1519-25. doi:10.4049/jimmunol.181.2.1519

78. Almqvist N, Lönnqvist A, Hultkrantz S, Rask C, Telemo E. Serum-derived exosomes from antigen-fed mice prevent allergic sensitization in a model of allergic asthma. Immunology (2008) 125(1):21-7. doi:10.1111/j.1365-2567. 2008.02812.x

79. Park J-A, Sharif AS, Tschumperlin DJ, Lau L, Limbrey R, Howarth P, et al. Tissue factor-bearing exosome secretion from human mechanically stimulated bronchial epithelial cells in vitro and in vivo. J Allergy Clin Immunol (2012) 130(6):1375-83. doi:10.1016/j.jaci.2012.05.031

80. Vargas A, Roux-Dalvai F, Droit A, Lavoie J-P. Neutrophil-derived exosomes: a new mechanism contributing to airway smooth muscle remodeling. Am J Respir Cell Mol Biol (2016) 55(3):450-61. doi:10.1165/rcmb.2016-0033OC

81. Kesimer M, Gupta R. Physical characterization and profiling of airway epithelial derived exosomes using light scattering. Methods (2015) 87:59-63. doi:10.1016/j.ymeth.2015.03.013

82. Agache I, Akdis C, Jutel M, Virchow JC. Untangling asthma phenotypes and endotypes.Allergy(2012)67(7):835-46.doi:10.1111/j.1398-9995.2012.02832.x
83. Suojalehto H, Toskala E, Kilpeläinen M, Majuri M-L, Mitts C, Lindström I, et al. MicroRNA profiles in nasal mucosa of patients with allergic and nonallergic rhinitis and asthma. Int Forum Allergy Rhinol (2013) 3(8):612-20. doi:10.1002/alr.21179

84. Suojalehto H, Lindström I, Majuri M-L, Mitts C, Karjalainen J, Wolff H, et al. Altered microRNA expression of nasal mucosa in long-term asthma and allergic rhinitis. Int Arch Allergy Immunol (2014) 163(3):168-78. doi: $10.1159 / 000358486$

85. Williams AE, Larner-Svensson H, Perry MM, Campbell GA, Herrick SE, Adcock IM, et al. MicroRNA expression profiling in mild asthmatic human airways and effect of corticosteroid therapy. PLoS One (2009) 4(6):e5889. doi:10.1371/journal.pone.0005889

86. Solberg OD, Ostrin EJ, Love MI, Peng JC, Bhakta NR, Hou L, et al. Airway epithelial miRNA expression is altered in asthma. Am J Respir Crit Care Med (2012) 186(10):965-74. doi:10.1164/rccm.201201-0027OC

87. Wu X-B, Wang M-Y, Zhu H-Y, Tang S-Q, You Y-D, Xie Y-Q. Overexpression of microRNA-21 and microRNA-126 in the patients of bronchial asthma. Int J Clin Exp Med (2014) 7(5):1307-12.

88. Martinez-Nunez RT, Bondanese VP, Louafi F, Francisco-Garcia AS, Rupani H, Bedke N, et al. A microRNA network dysregulated in asthma controls IL-6 production in bronchial epithelial cells. PLoS One (2014) 9(10):e111659. doi:10.1371/journal.pone.0111659

89. Jardim MJ, Dailey L, Silbajoris R, Diaz-Sanchez D. Distinct microRNA expression in human airway cells of asthmatic donors identifies a novel asthma-associated gene. Am J Respir Cell Mol Biol (2012) 47(4):536-42. doi:10.1165/rcmb.2011-0160OC

90. Roff AN, Craig TJ, August A, Stellato C, Ishmael FT. MicroRNA-570-3p regulates HuR and cytokine expression in airway epithelial cells. Am J Clin Exp Immunol (2014) 3(2):68-83.

91. Fang C, Lu W, Li C, Peng X, Wang Y, Huang X, et al. MiR-3162-3p is a novel microRNA that exacerbates asthma by regulating $\beta$-catenin. PLoS One (2016) 11(3):e0149257. doi:10.1371/journal.pone.0149257

92. Perry MM, Baker JE, Gibeon DS, Adcock IM, Chung KF. Airway smooth muscle hyperproliferation is regulated by microRNA-221 in severe asthma. Am J Respir Cell Mol Biol (2014) 50(1):7-17. doi:10.1165/ rcmb.2013-0067OC

93. Hu R, Pan W, Fedulov AV, Jester W, Jones MR, Weiss ST, et al. MicroRNA-10a controls airway smooth muscle cell proliferation via direct targeting of the PI3 kinase pathway. FASEB J (2014) 28(5):2347-57. doi:10.1096/fj.13-247247

94. Comer BS, Camoretti-Mercado B, Kogut PC, Halayko AJ, Solway J, Gerthoffer WT. MicroRNA-146a and microRNA-146b expression and antiinflammatory function in human airway smooth muscle. Am J Physiol Lung Cell Mol Physiol (2014) 307(9):L727-34. doi:10.1152/ajplung.00174.2014

95. Nakano T, Inoue Y, Shimojo N, Yamaide F, Morita Y, Arima T, et al. Lower levels of hsa-mir-15a, which decreases VEGFA, in the CD4+ T cells of pediatric patients with asthma. J Allergy Clin Immunol (2013) 132(5):1224-7. doi:10.1016/j.jaci.2013.06.041

96. Tsitsiou E, Williams AE, Moschos SA, Patel K, Rossios C, Jiang X, et al. Transcriptome analysis shows activation of circulating CD8+ $\mathrm{T}$ cells in patients with severe asthma. J Allergy Clin Immunol (2012) 129(1):95-103. doi:10.1016/j.jaci.2011.08.011

97. Simpson LJ, Patel S, Bhakta NR, Choy DF, Brightbill HD, Ren X, et al. A microRNA upregulated in asthma airway $\mathrm{T}$ cells promotes $\mathrm{TH} 2$ cytokine production. Nat Immunol (2014) 15(12):1162-70. doi:10.1038/ni.3026

98. Dong X, Xu M, Ren Z, Gu J, Lu M, Lu Q, et al. Regulation of CBL and ESR1 expression by microRNA-22-3p, 513a-5p and 625-5p may impact the pathogenesis of dust mite-induced pediatric asthma. Int J Mol Med (2016) 38(2):446-56. doi:10.3892/ijmm.2016.2634

99. Plank MW, Maltby S, Tay HL, Stewart J, Eyers F, Hansbro PM, et al. MicroRNA expression is altered in an ovalbumin-induced asthma model and targeting miR-155 with antagomirs reveals cellular specificity. PLoS One (2015) 10(12):e0144810. doi:10.1371/journal.pone.0144810

100. Maes T, Cobos FA, Schleich F, Sorbello V, Henket M, De Preter K, et al. Asthma inflammatory phenotypes show differential microRNA expression in sputum. J Allergy Clin Immunol (2016) 137(5):1433-46. doi:10.1016/j. jaci.2016.02.018

101. Pinkerton M, Chinchilli V, Banta E, Craig T, August A, Bascom R, et al. Differential expression of microRNAs in exhaled breath condensates of patients with asthma, patients with chronic obstructive pulmonary disease, 
and healthy adults. J Allergy Clin Immunol (2013) 132(1):217-9. doi:10.1016/j. jaci.2013.03.006

102. Sinha A, Yadav AK, Chakraborty S, Kabra SK, Lodha R, Kumar M, et al. Exosome-enclosed microRNAs in exhaled breath hold potential for biomarker discovery in patients with pulmonary diseases. JAllergy Clin Immunol (2013) 132(1):219-22. doi:10.1016/j.jaci.2013.03.035

103. Levänen B, Bhakta NR, Torregrosa Paredes P, Barbeau R, Hiltbrunner S, Pollack JL, et al. Altered microRNA profiles in bronchoalveolar lavage fluid exosomes in asthmatic patients. J Allergy Clin Immunol (2013) 131(3): 894-903. doi:10.1016/j.jaci.2012.11.039

104. Chen X, Ba Y, Ma L, Cai X, Yin Y, Wang K, et al. Characterization of microRNAs in serum: a novel class of biomarkers for diagnosis of cancer and other diseases. Cell Res (2008) 18(10):997-1006. doi:10.1016/j.jaci.2012.11.039

105. Lawrie CH, Gal S, Dunlop HM, Pushkaran B, Liggins AP, Pulford K, et al. Detection of elevated levels of tumour-associated microRNAs in serum of patients with diffuse large B-cell lymphoma. Br J Haematol (2008) 141(5):672-5. doi:10.1111/j.1365-2141.2008.07077.x

106. Elbehidy RM, Youssef DM, El-Shal AS, Shalaby SM, Sherbiny HS, Sherief LM, et al. MicroRNA-21 as a novel biomarker in diagnosis and response to therapy in asthmatic children. Mol Immunol (2016) 71:107-14. doi:10.1016/j. molimm.2015.12.015

107. Sawant DV, Yao W, Wright Z, Sawyers C, Tepper RS, Gupta SK, et al. Serum microRNA-21 as a biomarker for allergic inflammatory disease in children. MicroRNA (2015) 4(1):36-40. doi:10.2174/2211536604666150220232507

108. Lv Y, Qi R, Xu J, Di Z, Zheng H, Huo W, et al. Profiling of serum and urinary microRNAs in children with atopic dermatitis. PLoS One (2014) 9(12):e115448. doi:10.1371/journal.pone.0115448

109. Panganiban RPL, Pinkerton MH, Maru SY, Jefferson SJ, Roff AN, Ishmael FT. Differential microRNA epression in asthma and the role of miR-1248 in regulation of IL-5. Am J Clin Exp Immunol (2012) 1(2):154-65.

110. Panganiban RP, Wang Y, Howrylak J, Chinchilli VM, Craig TJ, August A, et al. Circulating microRNAs as biomarkers in patients with allergic rhinitis and asthma. J Allergy Clin Immunol (2016) 137(5):1423-32. doi:10.1016/j. jaci.2016.01.029

111. Rezaie J, Ajezi S, Avci ÇB, Karimipour M, Geranmayeh MH, Nourazarian A, et al. Exosomes and their application in biomedical field: difficulties and advantages. Mol Neurobiol (2017). doi:10.1007/s12035-017-0582-7

112. Almeida MI, Reis RM, Calin GA. MicroRNA history: discovery, recent applications, and next frontiers. Mutat Res (2011) 717(1-2):1-8. doi:10.1016/j. mrfmmm.2011.03.009

113. Mohammadi A, Mansoori B, Baradaran B. The role of microRNAs in colorectal cancer. Biomed Pharmacother (2016) 84:705-13. doi:10.1016/j. biopha.2016.09.099

114. Smolle MA, Calin HN, Pichler M, Calin GA. Noncoding RNAs and immune checkpoints-clinical implications as cancer therapeutics. FEBS J (2017) 284(13):1952-66. doi:10.1111/febs.14030

115. Fattore L, Costantini S, Malpicci D, Ruggiero CF, Ascierto PA, Croce CM, et al. MicroRNAs in melanoma development and resistance to target therapy. Oncotarget (2017) 8(13):22262-78. doi:10.18632/oncotarget.14763

116. Carotenuto F, Albertini MC, Coletti D, Vilmercati A, Campanella L, Darzynkiewicz Z, et al. How diet intervention via modulation of DNA damage response through microRNAs may have an effect on cancer prevention and aging, an in silico study. Int J Mol Sci (2016) 17(5):752. doi:10.3390/ ijms 17050752

117. Li Y, Chen P, Zu L, Liu B, Wang M, Zhou Q. MicroRNA-338-3p suppresses metastasis of lung cancer cells by targeting the EMT regulator Sox4. Am J Cancer Res (2016) 6(2):127-40.

118. Lu YC, Chang JT, Chan EC, Chao YK, Yeh TS, Chen JS, et al. miR-196, an emerging cancer biomarker for digestive tract cancers. J Cancer (2016) 7(6):650-5. doi:10.7150/jca.13460

119. Inamdar S, Nitiyanandan R, Rege K. Emerging applications of exosomes in cancer therapeutics and diagnostics. Bioeng Transl Med (2017) 2(1):70-80. doi:10.1002/btm2.10059
120. Hoshino A, Costa-Silva B, Shen T-L, Rodrigues G, Hashimoto A, Tesic MarkM, et al. Tumour exosome integrins determine organotropic metastasis. Nature (2015) 527(7578):329-35. doi:10.1038/nature15756

121. Wang M-J, Xu Y-Y, Huang R-Y, Chen X-M, Chen H-M, Han L, et al. Role of an imbalanced miRNAs axis in pathogenesis of psoriasis: novel perspectives based on review of the literature. Oncotarget (2017) 8(3):5498-507. doi:10.18632/oncotarget.12534

122. Molasy M, Walczak A, Szaflik J, Szaflik JP, Majsterek I. MicroRNAs in glaucoma and neurodegenerative diseases. JHum Genet (2017) 62(1):105-12. doi:10.1038/jhg.2016.91

123. Jones Buie JN, Goodwin AJ, Cook JA, Halushka PV, Fan H. The role of miRNAs in cardiovascular disease risk factors. Atherosclerosis (2016) 254:271-81. doi:10.1016/j.atherosclerosis.2016.09.067

124. Marí-Alexandre J, Sánchez-Izquierdo D, Gilabert-Estellés J, BarcelóMolina M, Braza-Boills A, Sandoval J. miRNAs regulation and its role as biomarkers in endometriosis. Int J Mol Sci (2016) 17(1):1-16. doi:10.3390/ ijms 17010093

125. Piedade D, Azevedo-Pereira JM. MicroRNAs, HIV and HCV: a complex relation towards pathology. Rev Med Virol (2016) 26(3):197-215. doi:10.1002/ rmv.1881

126. Huang X, Luo Y-L, Mao Y-S, Ji J-L. The link between long noncoding RNAs and depression. Prog Neuropsychopharmacol Biol Psychiatry (2017) 73:73-8. doi:10.1016/j.pnpbp.2016.06.004

127. Portal-Núñez S, Esbrit P, Alcaraz MJ, Largo R. Oxidative stress, autophagy, epigenetic changes and regulation by miRNAs as potential therapeutic targets in osteoarthritis. Biochem Pharmacol (2016) 108:1-10. doi:10.1016/j. bcp.2015.12.012

128. Mohsenin V. The emerging role of microRNAs in hypoxia-induced pulmonary hypertension. Sleep Breath (2016) 20(3):1059-67. doi:10.1007/ s11325-016-1351-y

129. Szymczak I, Wieczfinska J, Pawliczak R. Molecular background of miRNA role in asthma and COPD: an updated insight. Biomed Res Int (2016) 2016:7802521. doi:10.1155/2016/7802521

130. Mattes J, Collison A, Plank M, Phipps S, Foster PS. Antagonism of microRNA-126 suppresses the effector function of TH2 cells and the development of allergic airways disease. Proc Natl Acad Sci U S A (2009) 106(44):18704-9. doi:10.1073/pnas.0905063106

131. Collison A, Herbert C, Siegle JS, Mattes J, Foster PS, Kumar RK. Altered expression of microRNA in the airway wall in chronic asthma: miR126 as a potential therapeutic target. BMC Pulm Med (2011) 11(1):29. doi:10.1186/1471-2466-11-29

132. Qin $\mathrm{H}, \mathrm{Xu}$ B, Mei J, Li D, Liu J, Zhao D, et al. Inhibition of miRNA-221 suppresses the airway inflammation in asthma. Inflammation (2012) 35(4):1595-9. doi:10.1007/s10753-012-9474-1

133. Kumar M, Ahmad T, Sharma A, Mabalirajan U, Kulshreshtha A, Agrawal A, et al. Let-7 microRNA-mediated regulation of IL-13 and allergic airway inflammation. J Allergy Clin Immunol (2011) 128(5):1077-85. doi:10.1016/j. jaci.2011.04.034

134. Polikepahad S, Knight JM, Naghavi AO, Oplt T, Creighton CJ, Shaw C, et al. Proinflammatory role for let-7 microRNAs in experimental asthma. J Biol Chem (2010) 285(39):30139-49. doi:10.1074/jbc.M110.145698

Conflict of Interest Statement: The authors declare that the research was conducted in the absence of any commercial or financial relationships that could be construed as a potential conflict of interest.

Copyright ( 2017 Sastre, Cañas, Rodrigo-Muñoz and del Pozo. This is an openaccess article distributed under the terms of the Creative Commons Attribution License (CC BY). The use, distribution or reproduction in other forums is permitted, provided the original author(s) or licensor are credited and that the original publication in this journal is cited, in accordance with accepted academic practice. No use, distribution or reproduction is permitted which does not comply with these terms. 